\title{
Chryseobacterium taiwanense sp. nov., isolated from soil in Taiwan
}

\author{
Chun-Ju Tai, ${ }^{1}$ Hsiao-Ping Kuo, ${ }^{1}$ Fwu-Ling Lee, ${ }^{1}$ Han-Ken Chen, ${ }^{1}$ \\ Akira Yokota ${ }^{2}$ and Chi-Chu Lo ${ }^{3}$ \\ ${ }^{1}$ Bioresource Collection and Research Center, Food Industry Research and Development \\ Institute, PO Box 246, Hsinchu 30062, Taiwan \\ ${ }^{2}$ Institute of Molecular and Cellular Biosciences, The University of Tokyo, Yayoi 1-1-1, \\ Bunkyo-Ku, Tokyo 113-0032, Japan \\ ${ }^{3}$ Division of Bio-Pesticide, Taiwan Agricultural Chemicals and Toxic Substances Research \\ Institute, Council of Agriculture, Taiwan
}

Correspondence

Fwu-Ling Lee

fll@firdi.org.tw

\begin{abstract}
Among a large collection of Taiwanese soil isolates, a novel Gram-negative, rod-shaped, non-spore-forming, yellow-pigmented bacterial strain, Soil-3-27 ${ }^{\top}$, was isolated from farmland soil in Wu-Feng, Taiwan. The isolate was subjected to a polyphasic study including 16S rRNA gene sequencing, DNA-DNA hybridization, fatty acid analysis and comparative phenotypic characterization. The $16 \mathrm{~S}$ rRNA gene sequence analysis indicated that the organism belongs to the genus Chryseobacterium. The organism contains menaquinone MK- 6 as the predominant isoprenoid quinone and $15: 0$ iso (43\%), $17: 1$ iso $\omega 9 c(17 \cdot 5 \%)$ and $17: 0$ iso $3-\mathrm{OH}(16.6 \%)$ as the major fatty acids. Phylogenetically, the closest relatives of strain Soil-3-27 ${ }^{\top}$ are Chryseobacterium daecheongense, Chryseobacterium defluvii and Chryseobacterium taichungense with $96 \cdot 7-97 \cdot 2 \%$ sequence similarity. DNA-DNA hybridization showed relatedness values of $8 \cdot 5-24 \cdot 2 \%$ with these species. The DNA G $+C$ content is $36 \cdot 8 \mathrm{~mol} \%$. Strain Soil-3-27 ${ }^{\top}$ is clearly distinguishable from other Chryseobacterium species and represents a novel species, for which the name Chryseobacterium taiwanense sp. nov. is proposed. The type strain is strain Soil-3-27 $7^{\top}\left(=\right.$ BCRC $17412^{\top}=$ IAM $15317^{\top}=$ LMG $\left.23355^{\top}\right)$.
\end{abstract}

The genus Chryseobacterium, a member of the family Flavobacteriaceae initially proposed to group several bacterial species previously attributed to the genus Flavobacterium (Vandamme et al., 1994), currently consists of 13 species with Chryseobacterium gleum as the type species. Two additional species were recently transferred to the new genus Elizabethkingia (Kim et al., 2005). The name of the protein-deaminating taxon 'Chryseobacterium proteolyticum' (Yamaguchi \& Yokoe, 2000) was not validly published under the Rules of the Bacteriological Code (1990 Revision) (Lapage et al., 1992).

In the present study, the taxonomic position of a Taiwanese soil isolate was studied using a polyphasic approach. Based on 16S rRNA gene sequence similarity, DNA-DNA relatedness values, fatty acid content and phenotypic characterization, we propose the name Chryseobacterium taiwanense sp. nov. for this novel species.

Strain Soil-3-27 ${ }^{\mathrm{T}}$ was isolated on Luria-Bertani agar (USB) from a sample of farmland soil from Taiwan. The type

The GenBank/EMBL/DDBJ accession number for the $16 \mathrm{~S}$ rRNA gene sequence of strain BCRC $17412^{\top}$ is DO318789. strains of Chryseobacterium and Elizabethkingia species were received from culture collections. All strains were reactivated on trypticase soy agar (Difco) and checked for purity on nutrient agar (Difco) after cultivation at $30^{\circ} \mathrm{C}$ for 24-48 h. Strains were preserved at $-80^{\circ} \mathrm{C}$ in trypticase soy broth (Difco) with $10 \%$ (v/v) glycerol or by lyophilization. The patent strain ' $C$. proteolyticum' FERM P-17664 was included in the study using data from the NCBI database and literature (Yamaguchi \& Yokoe, 2000).

Genomic DNA was extracted and purified using the Qiagen Blood and Cell Culture DNA kit. The 16S rRNA genes were PCR-amplified and sequenced using the MicroSeq Full Gene 16S rDNA Bacterial Sequencing kit (PE Applied Biosystems). Sequencing was performed using an Applied Biosystem 310 DNA sequencer (PE Applied Biosystems). Sequence assembly was performed using the ABI Prism DNA Sequencing Analysis software (PE Applied Biosystems) and phylogenetic analyses were performed using the BioNumerics software (version 3.1; Applied Maths: http://www.applied-maths. com/), CLUSTAL_X (Thompson et al., 1997) and MEGA version 3.1 (Kumar et al., 2004). The consensus sequence of strain Soil-3-27 ${ }^{\mathrm{T}}$ was aligned with those of Chryseobacterium and Elizabethkingia species retrieved from the NCBI database. 
Sequences of Sejongia antarctica IMSNU $14040^{\mathrm{T}}$, Kaistella koreensis IAM $15050^{\mathrm{T}}$, Bergeyella zoohelcum ATCC $43767^{\mathrm{T}}$, Flavobacterium aquatile ATCC $11947^{\mathrm{T}}$, Riemerella anatipestifer ATCC $11845^{\mathrm{T}}$, Ornithobacterium rhinotracheale LMG 9086 ${ }^{\mathrm{T}}$, Weeksella virosa ATCC $43766^{\mathrm{T}}$ and Empedobacter brevis ATCC 14234 were also included in the phylogenetic analysis for comparative purpose. Phylogenetic trees were constructed using the neighbour-joining (Saitou \& Nei, 1987) and maximum-parsimony (Fitch, 1971) methods. The confidence values of branches on the neighbour-joining tree were determined by performing a bootstrap analysis with 1000 replicates.

DNA G + C content and DNA-DNA relatedness values were determined with genomic DNA prepared using a commercial kit (Genomic-tips; Qiagen). The DNA G + C content was determined using reversed-phase HPLC according to Tamaoka \& Komagata (1984) with slight modifications. Nucleotides were separated using a Cosmosil $5 \mathrm{C}_{18}$ column $(4 \cdot 0 \times 150 \mathrm{~mm})$ (Waters) in a mobile phase composed of $0.2 \mathrm{M} \mathrm{NH}_{4} \mathrm{H}_{2} \mathrm{PO}_{4} /$ acetonitrile $(20: 1, \mathrm{v} / \mathrm{v})$ at a flow rate of $1 \mathrm{ml} \mathrm{min}^{-1}$ at room temperature. Nucleotides were detected and quantified by absorption at $260 \mathrm{~nm}$. DNA relatedness values between the novel strain and the type strains of Chryseobacterium and Elizabethkingia species were determined using the fluorometric hybridization method in microdilution wells (Ezaki et al., 1989; Chern et al., 2004). The fluorescence intensity of each well was measured with a Fluoroskan II microplate fluorometer (Labsystems) at a wavelength of $360 \mathrm{~nm}$ for excitation and at $450 \mathrm{~nm}$ for emission. Hybridization temperature was $40^{\circ} \mathrm{C}$.

The fatty acid content was determined using the Sherlock Microbial Identification system (MIDI) as described previously (Chern et al., 2004). Extracts of the methylated fatty acids were prepared according to the protocol provided by the manufacturer and analysed with Agilent $6890 \mathrm{~N}$ gas chromatograph equipped with a flameionization detector and 7683 Automatic Liquid Sampler (Agilent). Identification of the peaks was made by comparing the results with the built-in TSBA 50 database (MIDI).

Respiratory quinones of the novel bacterium were determined according to Collins \& Jones (1981) and Komagata \& Suzuki (1987). The TLC-purified quinones were analysed with a Nova-Pak $\mathrm{C}_{18}(15 \times 3.9 \mathrm{~cm})$ column (Waters). Peaks were detected at $270 \mathrm{~nm}$ after elution with methanol/2propanol $(2: 1)$ at flow rate of $1 \mathrm{ml} \mathrm{min}^{-1}$.

All phenotypic tests were performed on bacteria grown on nutrient agar at $30^{\circ} \mathrm{C}$ unless otherwise specified. General cell morphology was studied using phase-contrast microscopy (Eclipse E600; Nikon). Gram reaction was performed using a 4-Step Gram Stain kit (Becton Dickinson) according to the manufacturer's instructions. Catalase activity, oxidase activity and oxidation-fermentation reactions were determined using standard methods (Barrow \& Feltham, 1993). Flexirubin-type pigments were detected according to Li et al.
(2003). Additional physiological and biochemical tests were performed using GN2 MicroPlate (Biolog), API 20E and API ZYM (bioMérieux) according to the manufacturer's instructions. A battery of tests was selected to differentiate among Gram-negative, yellow-pigmented bacteria (Holmes et al., 1984). Tests were performed at $30^{\circ} \mathrm{C}$ with different incubation times, as described by Cowan (1974), MacFaddin (1980) or Gerhardt et al. (1981), unless indicated otherwise.

The 16S rRNA gene sequence analysis showed that strain Soil-3-27 $7^{\mathrm{T}}$ belongs to the genus Chryseobacterium (Fig. 1). Although sequence similarities of $96 \cdot 7-97 \cdot 2 \%$ between strain Soil- $-3-27^{\mathrm{T}}$ and the type strains of $C$. daecheongense, C. defluvii and C. taichungense did not exclude a possible relationship at the species level with one of these taxa

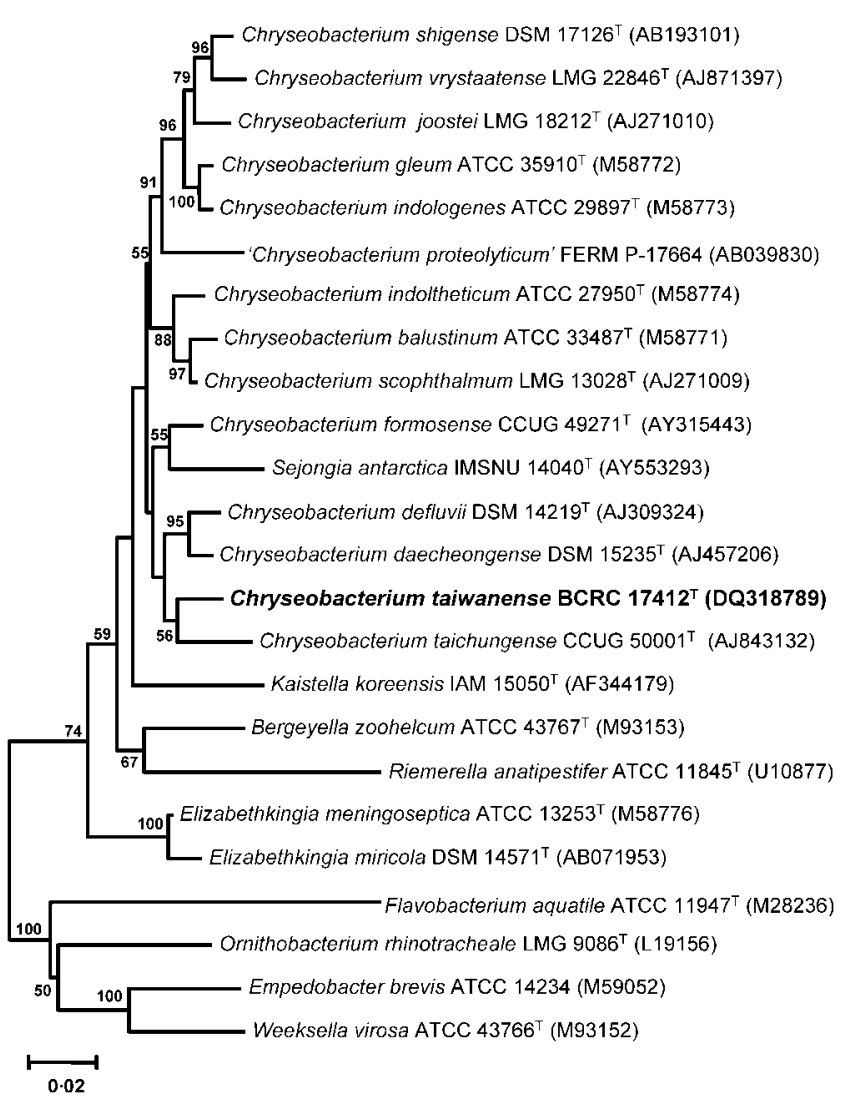

Fig. 1. Neighbour-joining phylogenetic tree based on $16 \mathrm{~S}$ rRNA gene sequences showing the relationships between Chryseobacterium species and related taxa in the family Flavobacteriaceae. The GenBank accession numbers for the sequences used in the analysis are given in parentheses. Bootstrap percentages (based on 1000 replicates) are given at the branching points. Flavobacterium aquatile ATCC $11947^{\top}$, Riemerella anatipestifer ATCC $11845^{\top}$, Weeksella virosa ATCC $43766^{\top}$ and Empedobacter brevis ATCC 14234 were used as the outgroup to root the tree. Bar, 0.02 substitutions per nucleotide position. 
Table 1. Fatty acid content of Chryseobacterium and Elizabethkingia species

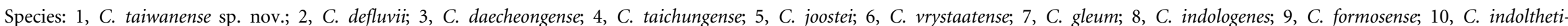

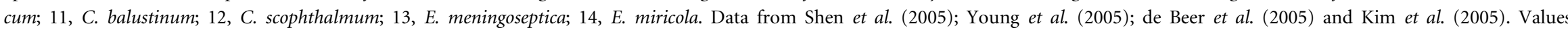
given are mean $\pm \mathrm{SD}$. tr, Trace (less than $1 \cdot 0 \%$ ); ND, not detected.

\begin{tabular}{|c|c|c|c|c|c|c|c|c|c|c|c|c|c|c|}
\hline Fatty acid & 1 & 2 & 3 & 4 & 5 & 6 & 7 & 8 & 9 & 10 & 11 & 12 & 13 & 14 \\
\hline $13: 0$ iso & $1 \cdot 0 \pm 0 \cdot 1$ & $4 \cdot 0 \pm 0 \cdot 1$ & $1 \cdot 3 \pm 0 \cdot 1$ & $\operatorname{tr}$ & $1 \cdot 3$ & $1 \cdot 1 \pm 0 \cdot 4$ & $\operatorname{tr}$ & $\operatorname{tr}$ & $3 \cdot 6$ & $\operatorname{tr}$ & $1 \cdot 7 \pm 0 \cdot 1$ & $\operatorname{tr}$ & $1 \cdot 3 \pm 0 \cdot 3$ & $2 \cdot 0 \pm 0 \cdot 5$ \\
\hline unknown $13 \cdot 565^{\star}$ & $2 \cdot 6 \pm 0 \cdot 1$ & $2 \cdot 9 \pm 0 \cdot 1$ & $1 \cdot 4 \pm 0 \cdot 4$ & $6 \cdot 4$ & $2 \cdot 0 \pm 0 \cdot 1$ & $1 \cdot 4 \pm 0 \cdot 3$ & $2 \cdot 7 \pm 0 \cdot 5$ & $2 \cdot 2 \pm 0 \cdot 2$ & $\operatorname{tr}$ & $2 \cdot 2 \pm 0 \cdot 3$ & $1 \cdot 9 \pm 0 \cdot 2$ & $3 \cdot 4 \pm 1 \cdot 0$ & $1 \cdot 9 \pm 0 \cdot 3$ & $1 \cdot 5 \pm 0 \cdot 2$ \\
\hline $15: 0$ iso & $43 \cdot 2 \pm 0 \cdot 7$ & $53 \cdot 2 \pm 0 \cdot 5$ & $46 \cdot 8 \pm 2 \cdot 1$ & $35 \cdot 4$ & $39 \cdot 6 \pm 0 \cdot 3$ & $41 \cdot 8 \pm 1 \cdot 4$ & $34 \cdot 4 \pm 0 \cdot 2$ & $33 \cdot 0 \pm 0 \cdot 4$ & $52 \cdot 2$ & $32 \cdot 6 \pm 0 \cdot 5$ & $35 \cdot 4 \pm 0 \cdot 3$ & $37 \cdot 4 \pm 0 \cdot 7$ & $43 \cdot 9 \pm 2 \cdot 0$ & $46 \cdot 4 \pm 2 \cdot 2$ \\
\hline $15: 0$ anteiso & $1 \cdot 0 \pm 0 \cdot 1$ & $1 \cdot 9 \pm 0 \cdot 1$ & 1 & $\operatorname{tr}$ & $\operatorname{tr}$ & $1 \cdot 7 \pm 0 \cdot 7$ & $\operatorname{tr}$ & $\operatorname{tr}$ & $3 \cdot 2$ & $6 \cdot 2$ & $1 \cdot 1$ & $\operatorname{tr}$ & $1 \cdot 1 \pm 0 \cdot 8$ & $1 \cdot 0 \pm 0 \cdot 6$ \\
\hline $16: 0$ & $1 \cdot 4 \pm 0 \cdot 1$ & $1 \cdot 5 \pm 0 \cdot 1$ & $1 \cdot 4$ & $1 \cdot 3$ & $1 \cdot 7$ & $1 \cdot 1 \pm 0 \cdot 3$ & $1 \cdot 8 \pm 0 \cdot 1$ & $2 \cdot 1 \pm 0 \cdot 1$ & $1 \cdot 5$ & $2 \cdot 0 \pm 0 \cdot 2$ & $3 \cdot 5 \pm 0 \cdot 1$ & $1 \cdot 6 \pm 0 \cdot 1$ & $\operatorname{tr}$ & $1 \cdot 2 \pm 0 \cdot 1$ \\
\hline $15: 0$ iso $3-\mathrm{OH}$ & $3 \cdot 8$ & $2 \cdot 5$ & $2 \cdot 8 \pm 0 \cdot 1$ & $4 \cdot 3$ & $2 \cdot 7$ & $2 \cdot 7 \pm 0 \cdot 3$ & $2 \cdot 9$ & $2 \cdot 8$ & $1 \cdot 8$ & $2 \cdot 2$ & $2 \cdot 5$ & $3 \cdot 0 \pm 0 \cdot 1$ & $2 \cdot 8 \pm 0 \cdot 3$ & $3 \cdot 0 \pm 0 \cdot 6$ \\
\hline $17: 1$ iso $\omega 9 c$ & $17 \cdot 5 \pm 0 \cdot 2$ & $60 \cdot 0 \pm 0 \cdot 2$ & $10 \cdot 8 \pm 0 \cdot 7$ & $8 \cdot 9$ & $19 \cdot 5 \pm 0 \cdot 1$ & $19 \cdot 7 \pm 2 \cdot 3$ & $21 \cdot 0 \pm 0 \cdot 5$ & $22 \cdot 2 \pm 0 \cdot 2$ & $4 \cdot 3$ & $20 \cdot 2 \pm 0 \cdot 4$ & $24 \cdot 5 \pm 0 \cdot 6$ & $22 \cdot 9 \pm 0 \cdot 2$ & $7 \cdot 8 \pm 1 \cdot 3$ & $6 \cdot 6 \pm 0 \cdot 2$ \\
\hline unknown $16 \cdot 582^{\star}$ & $0 \cdot 8 \pm 0 \cdot 2$ & $\operatorname{tr}$ & $1 \cdot 4 \pm 0 \cdot 1$ & $1 \cdot 7$ & $1 \cdot 0$ & $1 \cdot 2 \pm 0 \cdot 2$ & $1 \cdot 1$ & $1 \cdot 1$ & $1 \cdot 0$ & $\operatorname{tr}$ & $\operatorname{tr}$ & $\operatorname{tr}$ & $1 \cdot 6 \pm 0 \cdot 1$ & $1 \cdot 3 \pm 0 \cdot 6$ \\
\hline $17: 0$ iso & $1 \cdot 3 \pm 0 \cdot 1$ & $2 \cdot 6 \pm 0 \cdot 1$ & $\operatorname{tr}$ & $\operatorname{tr}$ & $2 \cdot 4$ & $\operatorname{Tr}$ & $2 \cdot 3$ & $1 \cdot 6 \pm 0 \cdot 1$ & $2 \cdot 3$ & $1 \cdot 6 \pm 0 \cdot 2$ & $3 \cdot 1$ & $1 \cdot 5 \pm 0 \cdot 1$ & $\operatorname{tr}$ & $\operatorname{tr}$ \\
\hline $16: 03-\mathrm{OH}$ & $\operatorname{tr}$ & $\operatorname{tr}$ & $\operatorname{tr}$ & $2 \cdot 6$ & $1 \cdot 0$ & $1 \cdot 3 \pm 0 \cdot 3$ & $1 \cdot 2$ & $1 \cdot 2$ & $\operatorname{tr}$ & $1 \cdot 2 \pm 0 \cdot 1$ & $1 \cdot 3$ & $1 \cdot 1 \pm 0 \cdot 1$ & $2 \cdot 6 \pm 0 \cdot 4$ & $3 \cdot 0 \pm 0 \cdot 6$ \\
\hline $17: 0$ iso $3-\mathrm{OH}$ & $16 \cdot 6 \pm 1 \cdot 1$ & $15 \cdot 6 \pm 0 \cdot 5$ & $20 \cdot 5 \pm 1 \cdot 6$ & $22 \cdot 4$ & $17 \cdot 9 \pm 0 \cdot 1$ & $15 \cdot 4 \pm 1 \cdot 8$ & $19 \cdot 3 \pm 0 \cdot 8$ & $18 \cdot 5 \pm 0 \cdot 3$ & $10 \cdot 9$ & $14 \cdot 5 \pm 0 \cdot 5$ & $15 \cdot 2 \pm 0 \cdot 4$ & $15 \cdot 9 \pm 1 \cdot 7$ & $14 \cdot 6 \pm 1 \cdot 0$ & $15 \cdot 3 \pm 0 \cdot 2$ \\
\hline $17: 02-\mathrm{OH}$ & $\operatorname{tr}$ & ND & $\operatorname{tr}$ & ND & ND & ND & ND & ND & ND & $3 \cdot 0 \pm 0 \cdot 3$ & $\operatorname{tr}$ & $\operatorname{tr}$ & $\mathrm{ND}$ & ND \\
\hline Summed feature $3 \dagger$ & $7 \cdot 9 \pm 0 \cdot 1$ & $7 \cdot 4 \pm 0 \cdot 2$ & $8 \cdot 8 \pm 0 \cdot 2$ & $\mathrm{ND}$ & $8 \cdot 4 \pm 0 \cdot 1$ & $9 \cdot 1 \pm 0 \cdot 9$ & $10 \cdot 4 \pm 0 \cdot 1$ & $11 \cdot 0 \pm 0 \cdot 2$ & ND & $9 \cdot 4 \pm 0 \cdot 1$ & $5 \cdot 6$ & $8 \cdot 3 \pm 0 \cdot 3$ & $\mathrm{ND}$ & $\mathrm{ND}$ \\
\hline Summed feature $4 \dagger$ & ND & ND & ND & $13 \cdot 8$ & ND & $\operatorname{tr}$ & ND & ND & $6 \cdot 5$ & ND & ND & ND & $19 \cdot 6 \pm 1 \cdot 0$ & $17 \cdot 0 \pm 1 \cdot 3$ \\
\hline Summed feature $5 \dagger$ & $\operatorname{tr}$ & ND & $\operatorname{tr}$ & $\mathrm{ND}$ & $\operatorname{tr}$ & ND & $\operatorname{tr}$ & $1 \cdot 2$ & ND & ND & ND & $\operatorname{tr}$ & $\operatorname{tr}$ & ND \\
\hline
\end{tabular}

*Unknown fatty acid; number indicates equivalent chain-length.

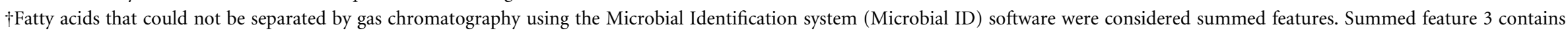

15:0 iso $2-\mathrm{OH}$ and/or $16: 1 \omega 7 c$. Summed feature 4 contains $15: 0$ iso $2-\mathrm{OH}$ and/or $16: 1 \omega 7 c / t$. Summed feature 5 contains $17: 1$ iso I and/or $17: 1$ anteiso B. 
(Vandamme et al., 1996), DNA-DNA relatedness values between the four strains were only $8 \cdot 5-24 \cdot 2 \%$. All other reference strains studied shared lower $16 \mathrm{~S}$ rRNA gene sequence similarity and insignificant DNA relatedness with strain Soil-3-27 $7^{\mathrm{T}}$. Therefore, the novel isolate represents a novel species in the genus Chryseobacterium.

Fatty acid content of strain Soil-3-27 ${ }^{\mathrm{T}}$ and related taxa (except ' $C$. proteolyticum' for which no data are available) are presented in Table 1. Only minor differences between strain Soil-3-27 ${ }^{\mathrm{T}}$ and other Chryseobacterium and Elizabethkingia species were noted. Dominant fatty acids for all strains investigated (mean level above $15 \%$ ) were $15: 0$ iso, $17: 0$ iso $3-\mathrm{OH}$ and $17: 1$ iso $\omega 9 c$ (Table 1 ). Strain Soil-3-27 contained menaquinone MK-6 as the predominant isoprenoid quinone; this is in accordance with all other members of the family Flavobacteriaceae.

Phenotypic features that distinguish the novel species from other Chryseobacterium and Elizabethkingia species are listed in Table 2 and in the species description.

\section{Description of Chryseobacterium taiwanense sp. nov.}

Chryseobacterium taiwanense (tai.wan.en'se. N.L. neut. adj. taiwanense, pertaining to Taiwan, the location of the soil sample from which the type strain was isolated).

Table 2. Differential phenotypic characteristics of Chryseobacterium and Elizabethkingia species

Species: 1, C. taiwanense sp. nov.; 2, C. defluvii; 3, C. daecheongense; 4, C. taichungense; 5, C. joostei; 6, C. vrystaatense; 7, C. shigense; 8, C. gleum; 9, C. indologenes; 10, C. formosense; 11, C. indoltheticum; 12, C. balustinum; 13, C. scophthalmum; 14, E. meningoseptica; 15, E. miricola. Data from Shen et al. (2005); Young et al. (2005); de Beer et al. (2005); Shimomura et al. (2005) and Kim et al. (2005). Only the type strain of each species was included. +, Positive; -, negative; w, weak; V, variable; NA, no data available. All strains tested are negative for nitrate reduction.

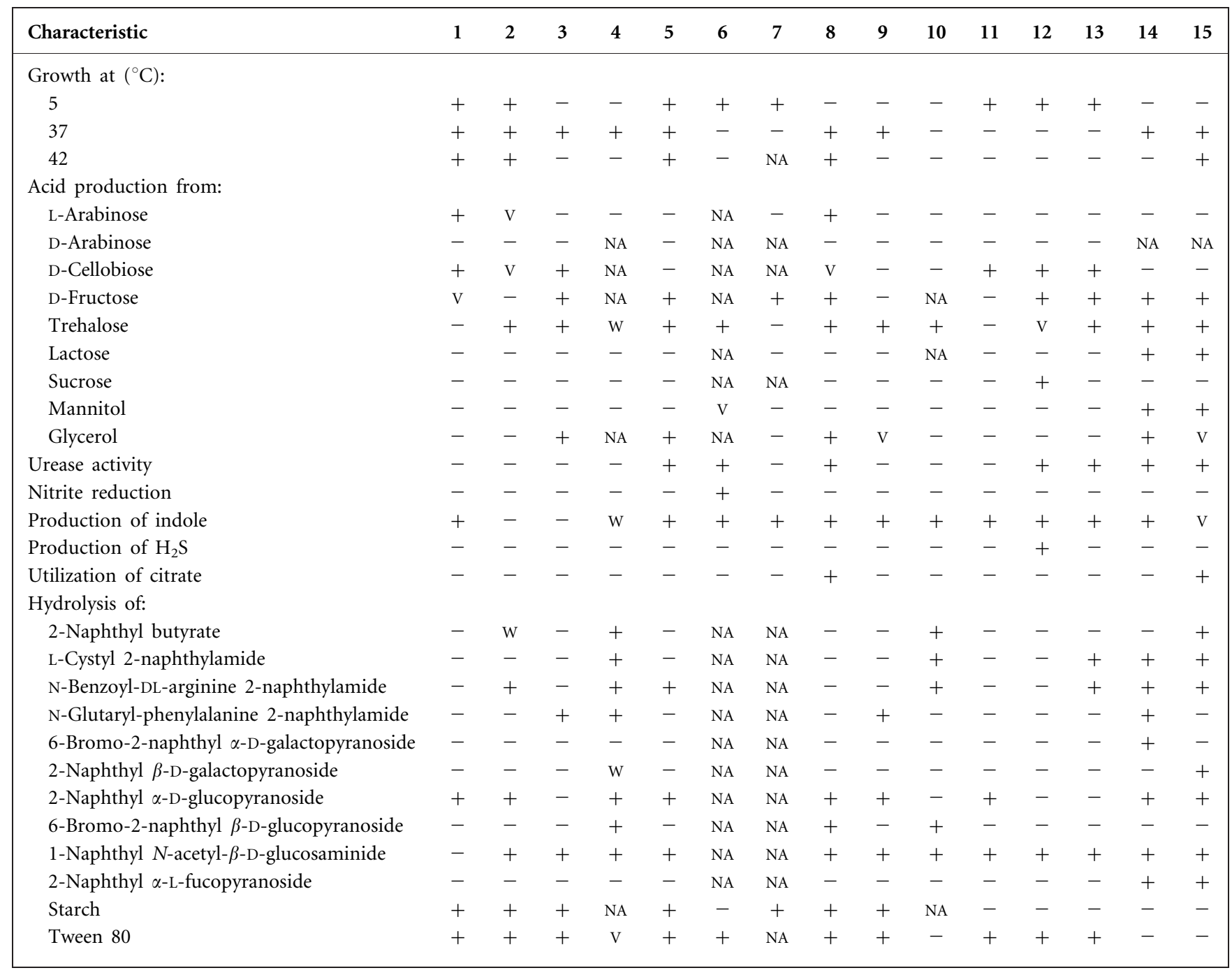


Gram-negative, non-spore-forming and non-motile rods $1 \cdot 06-2 \cdot 24 \times 0 \cdot 58-0 \cdot 85 \mu \mathrm{m}$ in size. Colonies are yellowish, translucent and shiny with entire edges. Growth occurs at $5-42{ }^{\circ} \mathrm{C}$ (optimum $30^{\circ} \mathrm{C}$ ) on trypticase soy agar. Growth does not occur below $5{ }^{\circ} \mathrm{C}$ or above $42^{\circ} \mathrm{C}$. The pH range for growth is 5-10 (optimum 6-8). Growth occurs on trypticase soy agar containing $4 \% \mathrm{NaCl}(\mathrm{w} / \mathrm{v})$. Catalase and oxidasepositive, urease activity is absent. Produces flexirubin-type pigments. Indole is produced. Tween 80 , casein, aesculin, gelatin and starch are hydrolysed. Acid is produced from $\alpha$-cyclodextrin, D-psicose, D-raffinose, glucuronamide, glycyl-L-glutamic acid, $\gamma$-aminobutyric acid, inosine, uridine, thymidine and glycerol. No acid is produced from any other substrate in GN2 MicroPlate. The following substrates are degraded in API ZYM strip: 2-naphthyl phosphate (at pH $8 \cdot 5$ and 5.4), 2-naphthyl caprylate, L-leucyl 2-naphthylamide, L-valyl 2-naphthylamide, naphthol-AS-BI phosphate and 2-naphthyl $\alpha$-D-glucopyranoside. The following substrates are not degraded in API ZYM strip: 2-naphthyl butyrate, 2-naphthyl myristate, L-cystyl 2-naphthylamide, $\mathrm{N}$-benzoyl-DL-arginine 2-naphthylamide, $\mathrm{N}$-glutaryl-phenylalanine 2-naphthylamide, 6-bromo-2-naphthyl $\alpha$-Dgalactopyranoside, 2 -naphthyl $\beta$-D-galactopyranoside, naphthol-AS-BI $\beta$-D-glucuronide, 6-bromo-2-naphthyl $\beta$ D-glucopyranoside, 1 -naphthyl- $N$-acetyl $\beta$-D-glucosaminide, 6 -bromo-2-naphthyl $\alpha$-D-mannopyranoside or 2 -naphthyl $\alpha$-L-fucopyranoside. The detailed fatty acid content and additional phenotypic features are given in Tables 1 and 2, respectively. Menaquinone MK-6 is the predominant respiratory quinone. Major fatty acids are $15: 0$ iso $(43 \%), 17: 1$ iso $\omega 9 c(17 \cdot 5 \%)$ and $17: 0$ iso $3-\mathrm{OH}(16 \cdot 6 \%)$. The $\mathrm{G}+\mathrm{C}$ content of the DNA is $36 \cdot 8 \mathrm{~mol} \%$.

The type strain is strain Soil- $3-27^{\mathrm{T}}\left(=\mathrm{BCRC} 17412^{\mathrm{T}}=\mathrm{IAM}\right.$ $\left.15317^{\mathrm{T}}=\mathrm{LMG} 23355^{\mathrm{T}}\right)$, isolated in the year 2000 from farmland soil in $\mathrm{Wu}-$ Feng, Taiwan.

\section{Acknowledgements}

We thank Professor J. Swings, Laboratory of Microbiology and LMG Bacteria Collection, Ghent University, Belgium, for his critical review of the manuscript and constructive and helpful comments. We would like to thank Dr Jean P. Euzéby for his valuable help with naming the species. Special thanks go to T. Y. Liu, C. C. Liao and G. F. Yuan (Food Industry Research and Development Institute, Taiwan) for their encouragement. This research was supported by the Taiwanese Ministry of Economic Affairs (project no. 05G270-03).

\section{References}

Barrow, G. I. \& Feltham, R. K. A. (1993). Cowan and Steel's Manual for the Identification of Medical Bacteria, 3rd edn. Cambridge: Cambridge University Press.

Chern, L.-L., Stackebrandt, E., Lee, S.-F., Lee, F.-L., Chen, J.-K. \& Fu, H.-M. (2004). Chitinibacter tainanensis gen. nov., sp. nov., a chitin-degrading aerobe from soil in Taiwan. Int J Syst Evol Microbiol 54, 1387-1391.
Collins, M. D. \& Jones, D. (1981). A note on the separation of natural mixtures of bacterial ubiquinones using reverse-phase partition thin-layer chromatography and high performance liquid chromatography. J Appl Bacteriol 51, 129-134.

Cowan, S. T. (1974). Cowan and Steel's Manual for the Identification of Medical Bacteria, 2nd edn. Cambridge: Cambridge University Press.

de Beer, H., Hugo, C. J., Jooste, P. J., Willems, A., Vancanneyt, M., Coenye, T. \& Vandamme, P. A. R. (2005). Chryseobacterium vrystaatense sp. nov., isolated from raw chicken in a chickenprocessing plant. Int J Syst Evol Microbiol 55, 2149-2153.

Ezaki, T., Hashimoto, Y. \& Yabuuchi, E. (1989). Fluorometric deoxyribonucleic acid-deoxyribonucleic acid hybridization in microdilution wells as an alternative to membrane filter hybridization in which radioisotopes are used to determine genetic relatedness among bacterial strains. Int J Syst Bacteriol 39, 224-229.

Fitch, W. M. (1971). Toward defining the course of evolution: minimum change for a specific tree topology. Syst Zool 20, 406-416.

Gerhardt, P., Murray, R. G. E., Costilow, R. N., Nester, E. W., Wood, W. A., Krieg, N. R. \& Phillips, G. B. (1981). Manual of Methods for General Bacteriology. Washington, DC: American Society for Microbiology.

Holmes, B., Owen, R. J., Steigerwalt, A. G. \& Brenner, D. J. (1984). Flavobacterium gleum, a new species found in human clinical specimens. Int J Syst Bacteriol 34, 21-25.

Kim, K. K., Kim, M. K., Lim, J. H., Park, H. Y. \& Lee, S. T. (2005). Transfer of Chryseobacterium meningosepticum and Chryseobacterium miricola to Elizabethkingia gen. nov. as Elizabethkingia meningoseptica comb. nov. and Elizabethkingia miricola comb. nov. Int J Syst Evol Microbiol 55, 1287-1293.

Komagata, K. \& Suzuki, K. (1987). Lipids and cell-wall analysis in bacterial systematics. Methods Microbiol 19, 161-203.

Kumar, S., Tamura, K. \& Nei, M. (2004). MEGA3: integrated software for molecular evolutionary genetics analysis and sequence alignment. Brief Bioinform 5, 150-163.

Lapage, S. P., Sneath, P. H. A., Lessel, E. F., Skerman, V. B. D., Seeliger, H. P. R. \& Clark, W. A. (1992). International Code of Nomenclature of Bacteria (1990 revision). Washington, DC: American Society for Microbiology.

Li, Y., Kawamura, Y., Fujiwara, N., Naka, T., Liu, H., Huang, X., Kobayashi, K. \& Ezaki, T. (2003). Chryseobacterium miricola sp. nov., a novel species isolated from condensation water of space station Mir. Syst Appl Microbiol 26, 523-528.

MacFaddin, J. F. (1980). Biochemical Tests for the Identification of Medical Bacteria, 2nd edn. Baltimore, MD: Williams \& Wilkins.

Saitou, N. \& Nei, M. (1987). The neighbor-joining method: a new method for reconstructing phylogenetic trees. Mol Biol Evol 4, 406-425.

Shen, F.-T., Kämpfer, P., Young, C.-C., Lai, W.-A. \& Arun, A. B. (2005). Chryseobacterium taichungense sp. nov., isolated from contaminated soil. Int J Syst Evol Microbiol 55, 1301-1304.

Shimomura, K., Kaji, S. \& Hiraishi, A. (2005). Chryseobacterium shigense sp. nov., a yellow-pigmented, aerobic bacterium isolated from a lactic acid beverage. Int J Syst Evol Microbiol 55, 1903-1906.

Tamaoka, J. \& Komagata, K. (1984). Determination of DNA base composition by reversed-phase high-performance liquid chromatography. FEMS Microbiol Lett 25, 125-128.

Thompson, J. D., Gibson, T. J., Plewniak, F., Jeanmougin, F. \& Higgins, D. G. (1997). The CLUSTAL_X windows interface: flexible strategies for multiple sequence alignment aided by quality analysis tools. Nucleic Acids Res 25, 4876-4882. 
Vandamme, P., Bernardet, J.-F., Segers, P., Kersters, K. \& Holmes, B. (1994). New perspectives in the classification of the flavobacteria: description of Chryseobacterium gen. nov., Bergeyella gen. nov., and Empedobacter nom. rev. Int J Syst Bacteriol 44, 827-831.

Vandamme, P., Pot, B., Gillis, M., de Vos, P., Kersters, K. \& Swings, J. (1996). Polyphasic taxonomy, a consensus approach to bacterial systematics. Microbiol Rev 60, 407-438.
Yamaguchi, S. \& Yokoe, M. (2000). A novel protein-deamidating enzyme from Chryseobacterium proteolyticum sp. nov., a newly isolated bacterium from soil. Appl Environ Microbiol 66, 3337-3343. Young, C.-C., Kämper, P., Shen, F.-T., Lai, W.-A. \& Arun, A. B. (2005). Chryseobacterium formosense sp. nov., isolated from the rhizosphere of Lactuca sativa L. (garden lettuce). Int J Syst Evol Microbiol 55, 423-426. 